\title{
The Effect of Otoprotective Substances Against Cisplatin Exposure: A Literature Review
}

\author{
José Luis Treviño Gonzalez* , Josefina Alejandra Morales-Del Ángel, Mario Jesús Villegas González, \\ Luis Ángel Garza Montelongo and Mauricio Moreyra Villarreal \\ Department of Otolaryngology and Head and Neck Surgery, University of Nuevo León, México
}

*Corresponding author: José Luis Treviño González, Department of Otolaryngology and Head and Neck Surgery, University Hospital “Dr. José Eleuterio González", University of Nuevo León, México

To Cite This Article: José Luis Treviño Gonzalez, Luis Ángel Garza Montelongo. The Effect of Otoprotective Substances Against Cisplatin Exposure: A Literature Review. 2020 - 9(2). AJBSR.MS.ID.001366. DOI: 10.34297/AJBSR.2020.09.001366.

Received: 眥 May 28, 2020; Published: 眥 June 12, 2020

\begin{abstract}
Introduction: Progressive and irreversible hearing loss is the most frequent side effect in

patients using platinum therapy for head and neck malignancies. Previous studies on cisplatin-induced ototoxicity have shown that accumulation of reactive oxygen species leads to oxidative stress and subsequent intracellular reactions, eventually leading to cell-death. The aim of this study is to review recent evidence about the use of different substances and their otoprotective effect in humans or animals exposed to cisplatin therapy.

Methods: Scientific databases such as PubMed and Cochrane were thoroughly searched from 14/04/20 to 02/05/20, based on the next keywords: cisplatin ototoxicity, cisplatin audition side effects, platinum induced ototoxicity, reduction of cisplatin ototoxicity, otoprotection against cisplatin. We include clinical trials, randomized controlled trials, reviews and systematic reviews published in English over the last five years.

Results and Discussion: Many substances have been used to experience their protective use in cisplatin exposure, but the minority have shown a positive effect in humans such as sodium thiosulfate and $\mathrm{N}$-acetylcysteine, some others are in the experimental phase in animals or in in-vivo phase and others have not shown favorable results at all.

Conclusion: Cisplatin has been reported to be a substance that can cause an important otoacoustic damage, but it is essential in the treatment of different types of cancer, so the benefit is worth the risk, but in order to avoid the ototoxic damage, otoprotective substances should be prescribed before and during the administration of cisplatin.
\end{abstract}

Keywords: Cisplatin ototoxicity, Cisplatin audition side effects, Platinum induced ototoxicity, Cisplatin ototoxicity, Reduction of cisplatin ototoxicity, Otoprotection against cisplatin.

Abbreviations: SGC: Spiral Ganglionar Cells, OCT-2: Organic Cation Transporter, CTR1: Copper Transport Protein, ROS: Reactive Oxygen Species, ABR: Auditory Brainstem Response, ALA: Alpha-Lipoic Acid, EGCG: Epigallocatechin-3-gallate, PBS: Phosphate Buffered Saline, NAC: N-Acetylcysteine, MTD: Maximum Tolerated Dose, FTO: Fat Mass and Obesity-associated protein, MA2: Meclofenamic Acid, SIRT1: NAD protein deacetylase Sirtuin 1.

\section{Highlights}

a. Hearing loss is a frequent side effect in platinum therapy

b. Reactive oxygen species production and oxidative stress cause ototoxicity

c. Only N-acetylcysteine and sodium thiosulfate showed otoprotective effect in humans

d. Dexamethasone formulations improved ABR low frequency response but remains experimental

\section{Introduction}

Cisplatin, oxaliplatin and carboplatin are the three most used platinum analogues, which have been proven to be effective as antineoplastic agents against a wide variety of malignancies such

as testicle, ovarian, gallbladder, large cell lung carcinoma, head and neck cancer, etc. [1]. Progressive and irreversible hearing loss is the most frequent side effect in patients using platinum therapy 
for head and neck malignancies. Otalgia, tinnitus and vestibular alterations are other common side effects found [2]. The prevalence of ototoxicity due to platinum analogues treatment ranges from $4 \%$ to $90 \%[3,4]$.

Recent research report that pediatric patients who undergo platinum analogues chemotherapy have cognitive and emotional development retardment. There is no treatment protocol established for patients with hearing loss due to platinum therapy and no prevention measures are defined for patients who require chemotherapy [5].

Survival rates of head and neck malignancies for pediatric and adult patients average $80 \%$ for some types of cancer treated with cisplatin, with irreversible hearing loss rates during treatment as high as 95\%. [1,6]. Currently, in the US there are 14.5 to 15.5 million of cancer treatment survivors, which they are expected to increase to 10 million in 2026 due to recent advances in early cancer detection and treatment, so a special focus is needed not only in the cure but in the quality of life care of people treated with chemotherapy $[2,7]$.

\section{Background}

Cisplatin is a well-known anticancer drug. The substance primarily causes cell death by intercalating DNA, leading to a major antineoplastic effect. However, the risk of ototoxic and nephrotoxic side effects commonly hinders the use of higher doses that could otherwise maximize its antineoplastic effects [8]. Clinically, cisplatin induced ototoxicity appears generally as a progressive, bilateral and irreversible sensorineural hearing loss at high frequencies and progresses towards the lower frequencies [9].

\section{Cochlea-Physiology}

The cochlea has high requirements of energy due to its increased metabolic activity. During mitochondrial ATP production process an electron leakage can occur reacting with oxygen to produce free radicals which in normal conditions are buffered by antioxidant cellular mediators. External situations such as platinum analogues therapy, could stimulate oxidative stress accelerating enzymes or inactivate antioxidant processes resulting in cochlear injury [10]. In normal conditions the cochlea has an efficient antioxidant defense system based on vitamins $\mathrm{C}$ and $\mathrm{E}$ and low molecular weight thiols, like glutathione. However, with increasing metabolic stress due to inherent pathologies additional antioxidant supplementation may be needed [11].

\section{Ototoxicity-Theory}

Cisplatin has a preference over three principal structures in the cochlea: Corti's organ, spiral ganglionar cells (SGC) and lateral wall (stria vascularis) [1]. Cisplatin is absorbed by the cochlear cells and stria vascularis by the Organic Cation Transporter (OCT-
2) and the Copper Transport Protein (CTR1) present in the cellular wall resulting in increasing cochlear cells cisplatin levels [3]. Previous studies on cisplatin-induced ototoxicity have shown that accumulation of reactive oxygen species (ROS) leads to oxidative stress and subsequent intracellular reactions, eventually leading to cell-death [8]. Excessive ROS can induce apoptosis through extrinsic and intrinsic pathways. Cellular stress, such DNA damage, results in the release of cytochrome-c from the mitochondria causing activation of procaspase- 9 through the interaction with apoptosis promoting activation of factor- 1 and formation of an active apoptosome complex [9].

Patient susceptibility is given by certain genes that may be related to other pathologies such as sensorineural sudden hearing loss and mitochondrial dysfunction $[7,12,13]$.

\section{Otoprotectors}

The following groups of drugs have been recently studied because of the interaction and protection role they have in the different processes of cochlear cell damage.

\section{Corticosteroids}

Dexamethasone is reported as an effective treatment alternative and clinical improvement measure against sensorineural sudden hearing loss, Meniere's disease or Bell's palsy. Blockage of inflammation mediators and cellular death may be the underlying mechanism by which steroids show clinical improvement in patients using cisplatin, so different dosage and compounds are being studied to facilitate absorption and administration [14].

DEX-SILK: Otoprotection efficacy of dexamethasone was analyzed in combination with

polyethylenglycol hydrogel. This compound is obtained by the subtraction of a protein produced by the Bombyx mori worm. There is evidence that intratympanic injections in mice model showed hearing improvement. A recent study, published in 2019, divided their sample in four groups: Control, Cisplatin, CisplatinDexamethasone and Cisplatin with DEX-SILK. All groups were evaluated with Auditory Brainstem Response (ABR) before and five days after intervention. Subjects in the Cisplatin/DEX-SILK group showed better low frequency response $(\mathrm{p}<0.05)$ than other groups. Additionally, the cisplatin/DEX-SILK group presented longer drug exposure with desirable levels 160 hours after administration and detectable levels 20 days after [15].

A666-DEX-NP: The A666 nanoparticle in combination with dexamethasone increases the

aforementioned specific affinity for lateral wall cells, proven in vivo and in vitro models. In vitro models showed increased protection significance over cell vitality $(\mathrm{p}<0.05)$ and better low frequency response evaluated by ABR [16]. 
Dexamethasone Formulation OTO-104: Dexamethasone suspension in combination with

$16 \%$ of poloxamer 407 , a hydrophilic non-ionic surfactant This compound was evaluated in guinea pigs model with bilateral intratympanic injections. Subjects were divided in 6 groups: saline solution, cisplatin alone, cisplatin in combination with OTO-104 $0.6 \%$, cisplatin with OTO-104 2\%, cisplatin with OTO-104 6\% and cisplatin-mifepristone with OTO-104. The acute administration of cisplatin $12 \mathrm{mg} / \mathrm{kg}$ caused profound hearing loss in all frequencies tested by ABR. A single dose of OTO-104 6\% showed almost a complete protection against cisplatin acute ototoxicity $(\mathrm{p}<0.05)$. OTO-104 was also effective against chronic cisplatin administration, but the otoprotective effect depended on dexamethasone nuclear receptor pathways. A single dose of dexamethasone or lower doses of 0T0-104 were not effective [17].

\section{Organic compounds}

Allicin: A sulfur compound subtracted from garlic (Allium sativum) from the Alliaceae

family. It was evaluated in mice as a preventive measure for vestibular damage due to cisplatin administration. Subjects were divided in three groups: the control group received intratympanic injections of saline solution $0.9 \%$, the second group received intratympanic cisplatin $(3 \mathrm{mg} / \mathrm{kg}$ ) while the third group received the same dose of cisplatin in combination with Allicin $(18.2 \mathrm{mg} /$ kg) 2 hours prior cisplatin administration. Subjects were sacrificed for saccule, utricle and ampullae anti-caspase 3 marking. Caspase 3 activation was increased in subjects with cisplatin alone intake compared to those with prior cisplatin administration [18].

Alpha-lipoic acid (ALA): Also known as thioctic acid or 1,2-dithiolane-3-pentanoic acid.

Effective for its ability to regenerate endogenous vitamins $\mathrm{C}$ and $\mathrm{E}$ and intracellular reduced glutathione. Kyung-Hee et al. studied the histological and physiological changes while using pre- and post-treatment with ALA in cisplatin-treated mice cochlea and cellular line House Ear Institute-Organ of Corti 1 (HEI-OC1). In Hei-OCI cells ALA reduces cisplatin-induced apoptotic cell death, increasing significantly $87 \%$ cell viability in those pretreated with 2 mM ALA. Post-treatment also showed 78\% cell viability with 1 mM. ALA also reduces ROS levels in HEI-OCI cells, demonstrated by fluorescence intensity with $2^{\prime}, 7^{\prime}$-dichlorofluorescein diacetate [19].

Ferulic acid: Found in the plants cell membrane. A study published in 2018 evaluated in in-

vitro HEI-OC1 cells along with administration of cisplatin $30 \mu \mathrm{m}$ with ferulic acid $1.2 \mathrm{mM}$ for $24 \mathrm{hrs}$. ARNm antioxidant enzyme levels (Gclc, Gpx2, SOD2 and catalase) were greater in the ferulic acid group compared with the cisplatin alone group $(p<0.05)[20]$.
C-phycocyanin (CPC): Blue phycobiliprotein found in cyanobacteria and algae with

antioxidant activities. In-vitro HEI-OC1 cells were treated with $0.1-20 \mu \mathrm{g} / \mathrm{mL}$ CPC for 1 hour prior to the administration of $30 \mu \mathrm{m}$ of cisplatin for 30 hours. It was observed that otoprotection measured by cells vitality was higher in the CPC group compared to the CPC group alone, with lower enzymatic levels of caspase $3(p<0.05)$ [21].

Epigallocatechin-3-gallate (EGCG): Epigallocatechin ester and gallic acid present in green

tea. Proven antioxidant action in in-vitro Corti's organ cells UB/OC-1 by inhibition of apoptosis inductor gene STAT1 and regulation of STAT3 was reported in a 2017 study. Borse V et al. realized ABR tests and administered orally EGCG $100 \mathrm{mg} / \mathrm{kg}$ for 4 hours on Wistar male rats. A single cisplatin dose was administered by intraperitoneal via for ABR testing 72 hours later. A significant clinical improvement was reported with average thresholds of $17.1 \pm 4.8,24.3 \pm 5.5$ and $34,3 \pm 6,9 \mathrm{~dB}$ on the 8,16 and $32 \mathrm{kHz}$ frequencies, respectively [22].

Capsaicin: This oleoresin is obtained from chili peppers. Capsaicin and cisplatin activate the

same receptors by different pathways. Capsaicin produces a transitory phosphorylation triggering STAT1 and the pro survival transcription factor Tyr705 p-STAT3 while cisplatin produces a constant STAT1 regulation that drives into inflammation and apoptosis. This compound was also evaluated as an otoprotection alternative against cisplatin in UB/OC-1 cells measuring STAT3 and STAT1 activation with capsaicin and cisplatin. ABR testing was realized in mice model prior $0.1 \mu \mathrm{m}$ in $50 \mu \mathrm{l}$ transtympanic capsaicin with phosphate buffered saline (PBS) injection versus PBS alone, intraperitoneal cisplatin $(11 \mathrm{mg} / \mathrm{kg})$ was administered 24 hours later for posterior ABR testing. Cisplatin had auditory impact 72 hours after administration. PBS had no significant protection effect on auditory thresholds compared with the capsaicin-PBS pretreatment group which showed a significant auditory thresholds improvement on ABR testing in 8, 16 and $32 \mathrm{kHz}$ frequencies [23].

\section{Inorganic Compounds}

Sodium Thiosulfate: Inorganic compound with antioxidant properties derived from thiol

ACCL0431. In a 38 pediatric-oncologic centers multicentric study, children were treated with thiosulfate sodium $16 \mathrm{~g} / \mathrm{m}^{2}$ administered 6 hours later after $200 \mathrm{mg} / \mathrm{m}^{2}$ cisplatin dose compared with the control group. Primary criteria were the evaluation of hearing loss incidence after 4 weeks after the last cisplatin therapy. Hearing loss was identified in 14 participants (28.6\%; IC 95\% 16.6-43.3) in the sodium thiosulfate group compared with 31 (56.4\%; 42.3-69.7) in the control group ( $\mathrm{p}=0.00022)$. Hearing loss probability was significantly lower in the sodium thiosulfate group 
compared with the control group (OR 0.31, IC 95\% 0. 13-0.73; $\mathrm{p}=0.0036$ ) [24]. Similar results were found in hepatoblastoma patients treated with cisplatin and sodium thiosulfate. Hearing loss grade 1 or greater was present in $33 \%$ of the patients in the cisplatin-sodium thiosulfate group compared with $63 \%$ of subjects in the cisplatin group [25].

N-acetylcysteine (NAC): A mucolytic agent precursor of the antioxidant glutathione, which

is used in acetaminophen intoxication, has mixed results as a otoprotective agent. Reports suggest that intravascular administration of NAC may act on reactive oxygen species producing immune cells that compromise the blood labyrinth barrier causing additional cochlear cisplatin uptake. Dosá et. al evaluated the NAC maximum tolerated dose (MTD) in patients with stage $\geq$ III renal failure who underwent digital subtraction angiography or non-isotonic nonionic contrast material, simulating cisplatin nephrotoxicity. Results showed $450 \mathrm{mg} / \mathrm{kg}$ as the NAC MTD both intravenous and intra-arterial safe administration, although phase II and III studies are needed to determine whether higher NAC intravenous and intra-arterial doses can avoid cisplatin induced ototoxicity or nephrotoxicity and which administration shows additional chemoprotection [26].

Meclofenamic acid (MA2): Fat mass and obesity-associated protein (FTO) is a m6A

demethylase that contributes to epigenetic RNA modification. Its dysregulation is related to obesity, brain development and chronic neurodegenerative diseases. In the inner ear, epigenetic RNA methylation dysregulation might play a major role in hearing loss, hearing protection and cell regeneration. MA2 is a nonsteroidal anti-inflammatory that blocks FTO binding for m6A containing nucleic acids. Previous in vitro HEI-OC1 cells reported that MA2 application during cisplatin treatment increased cell viability, attenuated induced apoptosis and autophagosome formation and reduced ROS levels [27].

Adenosine 1 Receptor: Cisplatin increases ROS levels via the NOX3-NADPH oxidase

pathway in the cochlea. Adenosine A1 Receptor protects against cisplatin ototoxicity by suppressing the inflammatory and apoptotic cascade. Kaur et al. evaluated transtympanic injections of the agonist R-phenyl isopropyl adenosine in rats, resulting in significantly attenuated cisplatin-induced changes in the cochlea and preserved hearing in the ABR thresholds at 8, 16 and $32 \mathrm{kHz}$ $(\mathrm{p}<0.05, \mathrm{n}=5)$ [28].

JWH015: CB2 agonist, (2-methyl-1-propyl-1H-indol-3-yl/1naphtalenylmethanone).

Previous in-vitro essays have shown an organ of Corti cell cisplatin induced apoptosis inhibition when the CB2 cannabinoid receptor is stimulated. S. Gosh et. al reported in rat models that transtympanic JWH015 (2.5 nmoles in PBS per ear) injection prior intraperitoneal cisplatin administration (11 mg/kg) acted as a chemoprotective agent. Pretreatment with JWH015 diminished ABR thresholds in all frequencies evaluated compared with the PBS alone group, which presented increased ranges of 5.01.5, 152.5, and 27.01.7 $\mathrm{dB}$ at 8, 16 and $32 \mathrm{kHz}$ [29].

SRT1720: Autophagy is known as a cellular process activated in conditions of stress or

starvation in order to promote cell survival. NAD protein deacetylase Sirtuin 1 (SIRT1) acts as autophagy modulator. Decreased levels have been related with age related hair cell loss and hearing loss in mice. Pang J. et al reported that the specific SIRT1 activator, SRT1720, alleviated cisplatin induced death in HEIOC1, zebrafish lateral line and mice cochlear hair cells [30].

\section{Nutritional antioxidants}

9.4.1.Vitamin E: Fat soluble antioxidant with the highest affinity for cellular walls. Previous in

vitro and animal models reported significant otoprotective results with no important effects on cisplatin's efficacy [31]. Cisplatin and Vitamin E $400 \mathrm{mg}$ were administered simultaneously in group 1 while group 2 only received placebo. Evoked brainstem responses and audiograms were evaluated at baseline, and after 1 , 2 and 3 months. At the 1 month audiogram, a significant hearing loss was reported in the control group at the $2000 \mathrm{HZ}$ and $8000 \mathrm{HZ}$ frequencies compared with the baseline results. ABR did not show any difference between groups. Patients were lost at the secondand third-month evaluation. More studies are needed to prove vitamin E efficacy against cisplatin ototoxicity [32].

Resveratrol: Polyphenol molecule with numerous antioxidant properties which inhibits

ototoxicity by reducing ROS. Symsek et al. compared the efficacy of intratympanic administration of dexamethasone and resveratrol in preventing cisplatin ototoxicity. They measured ABR and distortion product otoacoustic emissions (DPOAE) before and 72 hours after administration. Forty Wistar rats were divided in 5 groups (8 rats per group); group 1: cisplatin, group 2: cisplatin after resveratrol, group 3: dexamethasone after cisplatin, group 4: cisplatin after sodium chloride, group 5: cisplatin after dimethylsulfoxide. ABR thresholds valued after cisplatin administration were found to be less affected in rats that had been treated with dexamethasone and resveratrol ( $\mathrm{P}<0.001)$. DPOAE values were maintained in rats treated with dexamethasone and resveratrol $(\mathrm{P}<0.001)$ [33].

\section{Chelating Agents}

GMDTC: Sodium (S)-2-(dithiocarboxylato((2S,3R,4R, 5R)-2,3,4,5,6- pentahydroxyhexyl) 
amino)-4-(methylthio) butanoate derivative from the dithiocarbamates group. Acting as a monoanionic chelating agent that form stable complexes with all transition elements, forming GDMTC-platinum complex. Ge Y. et. reported GMDTC efficacy in decreasing cisplatin induced cisplatin ototoxicity compared with the control group, evaluated by ABR [34].

Pantoprazole: Inhibitor of the cation transporter 2. A study from 2018 used intravenous 1.6

$\mathrm{mg} / \mathrm{kg}$ over 4 hours along with cisplatin $(60 \mathrm{mg} / \mathrm{m} 2 \times 2$ days per cycle) in 12 patients. Pantoprazole did not show any significant results to attenuate cisplatin nephrotoxicity and ototoxicity [35].

\section{Other studies}

A double blind randomized clinical trial compared $\mathrm{N}$ acetylcysteine and Dexamethasone in a population of 57 patients. Dexamethasone had no effect compared to $\mathrm{N}$-acetylcysteine that shown beneficial results increasing hearing thresholds at higher frequencies such as 4000 and $8000 \mathrm{kHz}(\mathrm{p}<0.05)$ [36]. Caffeine has presented a positive correlation in rats exacerbating hearing loss [37]. Recent studies propose a benefit in the use of lithium chlorideinduced autophagy in rats under a cisplatin scheme [38-40].

Melatonin has proven to be useful against testicular and kidney cisplatin induced toxicity, but there are few studies that evaluate its otoprotective function in chemotherapy. J de Araujo et. al reported that DPOAE amplitudes in rats treated with cisplatin and melatonin were similar compared to the control group, with significant lower levels in subjects treated with cisplatin alone [41].

Amifostine is an organic phosphate reducing agent that is dephosphorylated into its active thiol metabolite. Its action mechanism is binding to cisplatin metabolites and lower ROS levels. There is no evidence yet to support the otoprotective role of amifostine against cisplatin therapy $[42,43]$.

Table 1: Summary of previous described substances and their evidence.

\begin{tabular}{|c|c|c|c|c|c|}
\hline Tested drug & Study & Target & Subject & Dosage & Results \\
\hline $\begin{array}{l}\text { Dexamethasone Formu- } \\
\text { lation OT0-104 }\end{array}$ & $\begin{array}{l}\text { Fernandez } \\
\text { R, } 2016 . \\
\text { Shi F, } 2019 .\end{array}$ & $\begin{array}{l}\text { Inflammato- } \\
\text { ry cytokines }\end{array}$ & $\begin{array}{c}\text { Female } \\
\text { Guinea Pigs } \\
(\mathrm{n}=12) \\
\text { In vitro HEI-OCI } \\
\text { cells / In vivo mice } \\
\text { model }\end{array}$ & $\begin{array}{l}\text { Cisplatin } \\
(12 \mathrm{mg} / \mathrm{kg})\end{array}$ & $\begin{array}{l}\text { The threshold change varies between } 12.5 \pm 2.5 \text { and } 0.0 \pm 5.0 \mathrm{~dB} \\
\text { from the baseline to day } 7 \text {, through the frequencies }(\mathrm{p}<0.001 \text { at the } \\
\qquad 3 \text { frequencies). (17) } \\
\text { The hydrogel provided significant protection against hearing loss } \\
\text { induced by cisplatin in mice at } 4,8 \text { and } 16 \mathrm{kHz} \text { in contrast with the } \\
\text { single administration of DEX-cisplatin. [15] }\end{array}$ \\
\hline Vitamin E & $\begin{array}{l}\text { V. Villani, } \\
2016\end{array}$ & $\begin{array}{l}\text { Antioxydant } \\
\text { ROS }\end{array}$ & Humans $(n=23)$ & $\begin{array}{l}\text { Cisplatin (400 } \\
\text { mg/day) } \\
\text { Vitamin E } \\
\text { (400 mg/day) } \\
\text { repeat } \\
3 \text { months } \\
\text { later. }\end{array}$ & $\begin{array}{l}\text { Preliminary results of the first month of treatment evaluated that } \\
\text { group with cisplatin alone had significant damage }(\mathrm{p}<.05) \text { while } \\
\text { the group with vitamin E no, in both groups no changes were found } \\
\text { in the ABR. [32] }\end{array}$ \\
\hline Allicin & Wu X, 2017 & Caspase-3 & $\begin{array}{l}\text { Mice model } \\
\qquad(n=10)\end{array}$ & $\begin{array}{c}\text { Allicin } \\
(18.2 \mathrm{mg} / \mathrm{kg}) \\
\text { Cisplatin } \\
(3 \mathrm{mg} / \mathrm{kg})\end{array}$ & $\begin{array}{l}\qquad \text { Allicin reduces levels of fluorescein } \\
\text { that capture the concentration of caspase-3 }(\mathrm{P}<0.05)[18]\end{array}$ \\
\hline $\begin{array}{l}\text { Epigallocatechin-3-gal- } \\
\text { late }\end{array}$ & Borse, 2017 & $\begin{array}{l}\text { STAT } 1 \\
\text { inhibitor }\end{array}$ & $\begin{array}{l}\text { In vitro HEI-OCI } \\
\text { cells / In vivo mice } \\
\text { model }\end{array}$ & $\begin{array}{c}\text { EGCG } \\
\text { (32 mg/kg) } \\
\text { Cisplatin } \\
\text { (2 mg/kg). }\end{array}$ & $\begin{array}{l}\text { Reduction of }(31.7 \pm 2.9 \%) \text { apoptotic cells under treatment with } \\
\text { EGCG compared to a group treated with Cisplatin }[22]\end{array}$ \\
\hline A 666-Dexamethasone & $\begin{array}{l}\text { Wang X, } \\
2018\end{array}$ & Caspase-3 & $\begin{array}{l}\text { In vitro HEI-OCI } \\
\text { cells / In vivo male } \\
\text { Guinea pigs }\end{array}$ & $\begin{array}{l}\text { Cisplatin } \\
(12 \mathrm{mg} / \mathrm{kg})\end{array}$ & $\begin{array}{l}\text { CDDP + A666-DEX-NP demonstrated a significant protective effect } \\
\text { compared to a group of pure cisplatin in the frequencies at } 4 \mathrm{kHz} \\
\text { (P: } 0.001), 8 \mathrm{kHz}(\mathrm{P}: 0.001) \text { y } 16 \mathrm{kHz}(\mathrm{P}: 0.05) .[16]\end{array}$ \\
\hline JWH015 & $\begin{array}{l}\text { Ghosh S, } \\
2018\end{array}$ & CB-2 & $\begin{array}{l}\text { Male } \\
\text { Rats }(n=12)\end{array}$ & $\begin{array}{l}\text { Cisplatin } \\
(11 \mathrm{mg} / \mathrm{kg}) \\
\text { JWH015 } \\
\text { (2.5 nmoles } \\
\text { in PBS per } \\
\text { ear) }\end{array}$ & $\begin{array}{l}\text { The ABR I wavelength obtained by } 60-90 \mathrm{~dB} \text { SPL tones delivered at } \\
32 \mathrm{kHz} \text { were reduced by } 33 \% \text { (from } 0.69 \pm 0.03 \mu \mathrm{V} \text { to } 0.46 \pm 0.04 \\
\qquad \mu \mathrm{V} \text { ) after treatment with cisplatin }(\mathrm{p}<0.0001 \text { ) [29] }\end{array}$ \\
\hline
\end{tabular}




\begin{tabular}{|c|c|c|c|c|c|}
\hline Pantoprazole & Fox E, 2018 & $\begin{array}{l}\text { Copper } \\
\text { transport- } \\
\quad \text { er } 2\end{array}$ & Children (n=12) & $\begin{array}{c}\text { Cisplatin } \\
\text { (60 mg/m2 } \\
3-2 \text { days per } \\
\text { cycle) } \\
\text { Pantoprazole } \\
\text { (intravenous } \\
\text { [IV], } 1,6 \mathrm{mg} \\
\text { / kg for } 4 \\
\text { hours) }\end{array}$ & $\begin{array}{l}\text { No significant difference was found between the control groups and } \\
\text { the pantoprazole administration group }(p=.18)[35]\end{array}$ \\
\hline Sodium Thiosulfate & $\begin{array}{l}\text { P. Brock, } \\
2018\end{array}$ & Antioxidant & $\begin{array}{l}\text { Children } \\
\text { (109) }\end{array}$ & $\begin{array}{c}\text { Cisplatin } \\
\text { (80mg/ } \\
\text { square meter } \\
\text { of body sur- } \\
\text { face) } \\
\text { Sodium } \\
\text { Thiosulfate } \\
(20 \mathrm{mg} / \mathrm{m})\end{array}$ & $\begin{array}{l}\text { Adding Thiosulfate to Cisplatin leads to a reduction of hearing loss } \\
\text { by } 48 \% \text {. Hearing Loss grade }>1 \text { occurred in } \\
63 \% \text { of the children that not received oto protection. [25] }\end{array}$ \\
\hline Capsaicin & $\begin{array}{l}\text { Bhatta P, } \\
2019\end{array}$ & CB2 & $\begin{array}{l}\text { In vitro } \mathrm{UB} / \mathrm{OC}-1 \\
\text { cells / In vivo rat } \\
\text { model }\end{array}$ & $\begin{array}{l}\text { Cisplatin } \\
(11 \mathrm{mg} / \mathrm{kg})\end{array}$ & $\begin{array}{l}\text { Administrating capsaicin between } 10 \text { to } 20 \mathrm{mg} / \mathrm{kg} \text { has a protective } \\
\text { effect (statistical significance) } \\
\text { [23] }\end{array}$ \\
\hline C-phycocyanin & Kim Y, 2019 & BAX y BCL-2 & $\begin{array}{l}\text { In Vitro HEI-OCI } \\
\quad \text { cells }\end{array}$ & $\begin{array}{c}\text { C-PC } \\
(1 \mu \mathrm{g} / \mathrm{ML}) \\
\text { Cisplatin } \\
(30 \mu \mathrm{M}) \text { for } \\
30 \mathrm{hrs} .\end{array}$ & $\begin{array}{c}\text { The vitality of the cells in the C-CP VS group, the cisplatin group was } \\
\text { higher }(\mathrm{p}<.05) \text {, just as the expression of caspase } 3 \text { was lower in the } \\
\text { group administered with C-PC }(\mathrm{P}<.05 .(21)\end{array}$ \\
\hline DEX-SILK & Shi F, 2019 & $\begin{array}{l}\text { Pro inflam- } \\
\text { matory } \\
\text { cytokines }\end{array}$ & $\begin{array}{l}\text { In vitro HEI-OCI } \\
\text { cells / In vivo mice } \\
\text { model }\end{array}$ & & $\begin{array}{l}\text { ABR was performed before the intervention and after } 5 \text { days of } \\
\text { treatment, showing significant protection in subjects treated with } \\
\text { the DEX-SILK compound }(\mathrm{p}<.05)(15)\end{array}$ \\
\hline Ferulic Acid & Jo ER, 2019 & Antioxydant & $\begin{array}{l}\text { In vitro HEI-OCI } \\
\text { cells / In vivo mice } \\
\text { model }\end{array}$ & $\begin{array}{l}\text { Cisplatin } \\
(30 \mu \mathrm{M}) \\
\text { for } 24 \mathrm{hrs} . \\
\text { Ferulic Acid } \\
(1,2 \mathrm{mM}) \text { of } \\
\text { for } 24 \mathrm{hrs} \text {. }\end{array}$ & $\begin{array}{l}\text { The mRNA level of antioxidant enzymes, Gclc, Gpx2, catalase and } \\
\text { SOD2 in previous treatment with ferulic acid increased compared } \\
\text { to those in the single cisplatin treatment group }(\mathrm{p}<0.05)(20)\end{array}$ \\
\hline GMDTC & $\begin{array}{l}\text { Ge Y, } \\
2019\end{array}$ & $\begin{array}{l}\text { Platinum } \\
\text { Chelator }\end{array}$ & $\begin{array}{l}\text { In vitro cultured } \\
\text { HK2 cells / In vivo } \\
\text { Female } \\
\text { Mice model }\end{array}$ & $\begin{array}{l}\text { Cisplatin } \\
\text { (5 mg/kg) } \\
2 \text { times per } \\
\text { week } \\
\\
\text { GMDTC (500 } \\
\text { mg/kg/day) }\end{array}$ & $\begin{array}{l}\text { Protection over low frequencies evaluated by evoked potentials } \\
\text { (statistically significant) (34) }\end{array}$ \\
\hline SIRT1 & Pang J, 2019 & CB2 & $\begin{array}{l}\text { In vitro HEI-OCI } \\
\text { cells / In vivo mice } \\
\quad(\mathrm{n}=45)\end{array}$ & $\begin{array}{c}\text { Cisplatin } \\
(16 \mathrm{mg} / \mathrm{kg}) \\
\text { SIRT1 (100 } \\
\mathrm{mg} / \mathrm{kg}) \\
12 \mathrm{hrs} \mathrm{pre,} 1 \\
\mathrm{hr} \text { pre, } \\
12 \mathrm{hrs} \\
\text { post-cisplatin } \\
\text { application }\end{array}$ & $\begin{array}{l}\text { Significantly reduced displacement of auditory thresholds mediated } \\
\text { by Cisplatin at various frequencies. } \\
\text { Also, significantly reduced the loss of outer hair cells in exposure to } \\
\text { Cisplatin alone }(\mathrm{p}<.05)(30)\end{array}$ \\
\hline
\end{tabular}




\begin{tabular}{|c|c|c|c|c|c|}
\hline Adenosine 1 Receptor & $\begin{array}{l}\text { Kaur T, } \\
2016\end{array}$ & $\begin{array}{c}\text { STAT } 1 \\
\text { inhibitor }\end{array}$ & $\begin{array}{l}\text { Male Wistar rats } \\
\text { model }\end{array}$ & $\begin{array}{l}\text { Intraperito- } \\
\text { neal Cisplatin } \\
(11 \mathrm{mg} / \mathrm{kg}) \\
\text { R-PIA }(1 \mu \mathrm{M})\end{array}$ & $\begin{array}{l}\text { Significantly attenuated cisplatin-induced changes in the cochlea } \\
\text { and preserved hearing in the ABR thresholds at } 8,16 \text { and } 32 \mathrm{kHz} \\
\qquad(\mathrm{p}<0.05, \mathrm{n}=5)(28)\end{array}$ \\
\hline Melatonin & $\begin{array}{l}\text { J. de Araujo, } \\
\quad 2019\end{array}$ & & $\begin{array}{l}\text { Wistar rats model } \\
\qquad(\mathrm{n}=32)\end{array}$ & $\begin{array}{l}\text { Intraperitone- } \\
\text { al melatonin } \\
\text { solution }(1 \\
\mathrm{mg} / \mathrm{kg}, 4 \\
\text { doses) } \\
\text { Intraperito- } \\
\text { neal cisplatin } \\
(10 \mathrm{mg} / \mathrm{kg})\end{array}$ & $\begin{array}{l}\text { DPOAE amplitudes were similar between control group and cispla- } \\
\text { tin-melatonin group, compared with a significant decrease in the } \\
\text { cisplatin group. (41) }\end{array}$ \\
\hline Resveratrol & $\begin{array}{l}\text { Simsek G, } \\
\quad 2019\end{array}$ & Antioxidant & $\begin{array}{l}\text { Female Wistar } \\
\text { rats model } \\
\qquad(\mathrm{n}=40)\end{array}$ & $\begin{array}{c}\text { Intratympanic } \\
\text { Resveratrol } \\
(20 \mathrm{mg} / \mathrm{kg}) \\
\\
\\
\text { Cisplatin } \\
(15 \mathrm{mg} / \mathrm{kg}) \\
30 \mathrm{~min} \text { after } \\
\text { resveratrol } \\
\text { application }\end{array}$ & $\begin{array}{l}\text { DPOAE measurements were taken before and } 72 \mathrm{~h} \text { after the medi- } \\
\qquad \text { cations } \\
\text { ABR threshold values after cisplatin administration were found to } \\
\text { be less affected in rats that had been treated with dexamethasone } \\
\qquad \text { and resveratrol }(\mathrm{P}<0.001) \\
\text { Otoacoustic emissions values were maintained in rats that had been } \\
\text { treated with dexamethasone and resveratrol }(\mathrm{P}<0.001)(33)\end{array}$ \\
\hline Alpha Lipoic Acid & Kim K, 2018 & Antioxidant & $\begin{array}{l}\text { In vitro HEI-OCI } \\
\text { cells / In vivo mice }\end{array}$ & $\begin{array}{c}\text { In vivo } \\
\text { Intraperito- } \\
\text { neal Cisplatin } \\
(20 \mathrm{mg} / \mathrm{kg}) \\
\text { ALA }(100 \mathrm{mg} / \\
\mathrm{kg}) \\
\text { In vitro } \\
\text { Cisplatin } \\
(30 \mu \mathrm{M}) \\
\text { ALA }(1 \mu \mathrm{M}) \\
\end{array}$ & $\begin{array}{l}\text { In HEI-OCI cells ALA reduces cisplatin-induced apoptotic cell death } \\
\text { ALA also reduces ROS levels in HEI-OCI cells, demonstrated by } \\
\text { fluorescence intensity (19) }\end{array}$ \\
\hline Meclofenamic Acid & H. Li, 2018 & $\begin{array}{l}\text { Fat Mass } \\
\text { and Obesity } \\
\text { associated } \\
\text { protein }\end{array}$ & $\begin{array}{l}\text { In Vitro HEI-OCI } \\
\text { cells }\end{array}$ & $\begin{array}{l}\text { MA2 }(80 \mu \mathrm{M} \\
\text { for } 2 \text { hours }) \\
\text { Cisplatin (15 } \\
\mu \text { M for } 48 \\
\text { hours) }\end{array}$ & $\begin{array}{l}\text { MA2 significantly reduced ROS, cell apoptosis and up regulation } \\
\text { autophagy. (27) }\end{array}$ \\
\hline
\end{tabular}

The ototoxicity due to cisplatin represents an important comorbidity, further studies in humans are needed. Clinical trials in humans have compared other ototoxic drugs such as aminoglycosides that also have an important association with ROS production. As the case of aspirin, which had a protective effect against gentamicin, but when its clinical benefits were tested in 94 patients undergoing cisplatin the cumulative dose of $200 \mathrm{mg} / \mathrm{m} 2$ no significant effect was reported [44] (Table 1).

\section{Conclusion}

Different substances and drugs with significant otoprotective results studied in in-vitro phase, promises to initiate experimental animal phase soon. A666-DEX-NP, OT0104 and DEX-SILK dexamethasone formulations showed benefits in experimental animal phase, but still have to be human proved.

Only N-acetylcysteine and Sodium Thiosulfate have reported significant otoprotective effects in human clinical trials. Vitamin E has also shown positive but preliminary results. The substances studied act by different mechanisms but at the end somehow can provide additional protection in cisplatin exposed individuals. This provides a huge opportunity area to appeal the ototoxicity caused by cisplatin.

More comparative studies between proposal otoprotective therapies are needed, although, with the information collected, we can advise decreasing or eliminating caffeine in patients who 
are under treatment with cisplatin. We also recommend the consumption of antioxidants such as Vitamin E and Vitamin C. Finally, we recommend a periodic undefined time audiometry during the treatment with cisplatin for the appropriate approach in case of presenting an auditory alteration or to adjust the correct therapeutic dose.

\section{Acknowledgements}

We thank our medical colleagues Nadia Gabriela Jasso Ramírez, Fernando Balderas Elizondo, Mauricio Moreyra Villarreal, Jacinto Eduardo Treviño Cárdenas, Adriana Miroslava Pérez Peña, Julian Antonio Contreras López and Eber Adrián Medina Estrada for helping in this paper.

\section{Declaration of Interest}

The author reports no conflicts of interest in this work.

\section{Funding sources}

This research did not receive any specific grant from funding agencies in the public, commercial, or not-for-profit sectors.

\section{References}

1. Sheth S, Mukherjea D, Rybak LP, Ramkumar V (2017) Mechanisms of Cisplatin-Induced Ototoxicity and Otoprotection. Front Cell Neurosci 11: 338.

2. Prayuenyong P, Taylor JA, Pearson SE, Gomez R, Patel PM, et al. (2018) Vestibulotoxicity Associated With Platinum-Based Chemotherapy in Survivors of Cancer: A Scoping Review. Front Oncol 8: 363.

3. Landier W (2016) Ototoxicity and cancer therapy. Cancer 122(11): 1647-1658.

4. Harrison RT, DeBacker JR, Bielefeld EC (2015) A low-dose regimen of cisplatin before high-dose cisplatin potentiates ototoxicity. Laryngoscope 125(2): E78-83.

5. Minasian LM, Frazier AL, Sung L, O Mara A, Kelaghan J, et al. (2018) Prevention of cisplatin-induced hearing loss in children: Informing the design of future clinical trials. Cancer Med 7(7): 2951-2959.

6. Drögemöller BI, Wright GEB, Lo C, Le T, Brooks B, et al. (2019) Pharmacogenomics of Cisplatin-Induced Ototoxicity: Successes, Shortcomings and Future Avenues of Research. Clin Pharmacol Ther 106(2): 350-359.

7. Tserga E, Nandwani T, Edvall NK, Bulla J, Patel P, et al. (2019) The genetic vulnerability to cisplatin ototoxicity: a systematic review. Sci Rep 9(1): 3455 .

8. Choi M-J, Kang H, Lee YY, Choo O-S, Jang JH, et al. (2019) CisplatinInduced Ototoxicity in Rats Is Driven by RIP3-Dependent Necroptosis. Cells 8(5): 409.

9. Waissbluth S (2020) Clinical trials evaluating transtympanic otoprotectants for cisplatin induced ototoxicity: what do we know so far? Eur Arch Otorhinolaryngology.

10. Oun R, Moussa YE, Wheate NJ (2018) The side effects of platinum-based chemotherapy drugs: A review for chemists. Dalton Trans 47(19): 66456653.

11. Laurell G (2019) Pharmacological intervention in the field of ototoxicity. HNO 67(6): 434-439.

12. Tate AD, Antonelli PJ, Hannabass KR, Dirain CO (2017) MitochondriaTargeted Antioxidant Mitoquinone Reduces Cisplatin-Induced Ototoxicity in Guinea Pigs. Otolaryngol Head Neck Surg 156(3): 543-548.
13. Fujimoto C, Yamasoba T (2019) Mitochondria-Targeted Antioxidants for Treatment of Hearing Loss: A Systematic Review. Antioxidants 8(4): 109.

14. Dinh CT, Chen S, Bas E, Dinh J, Goncalves S, et al. (2015) Dexamethasone protects against apoptotic cell death of cisplatin-exposed auditory hair cells in vitro. Otol Neurotol 36(9): 1566-1571.

15. Shi F, Wang X, Wang X, Yu D, Wu H, et al. (2019) Dexamethasone-loaded injectable silk-polyethylene glycol hydrogel alleviates cisplatin-induced ototoxicity. Int J Nanomedicine 14: 4211-4227.

16. Wang X, Chen Y, Tao Y, Gao Y, Yu D, et al. (2018) A666-conjugated nanoparticles target prestin of outer hair cells preventing cisplatininduced hearing loss. Int J Nanomedicine 13: 7517-7531.

17. Fernandez R, Harrop-Jones A, Wang X, Dellamary L, Lebel C, et al. (2016) The sustained-exposure dexamethasone formulation 0T0-104 offers effective protection against cisplatin-induced hearing loss. Audiol Neurootol 21(1): 22-29.

18. Wu X, Cai J, Li X, Li H, Li J, et al. (2017) Allicin protects against cisplatininduced vestibular dysfunction by inhibiting the apoptotic pathway. Eur J Pharmacol 805: 108-117.

19. Kim KH, Lee B, Kim YR, Kim MA, Ryu N, et al. (2018) Evaluating protective and therapeutic effects of alpha-lipoic acid on cisplatininduced ototoxicity. Cell Death Dis 9(8): 927.

20. Jo ER, Youn CK, Jun Y, Cho S Il (2019) The protective role of ferulic acid against cisplatin-induced ototoxicity. Int J Pediatr Otorhinolaryngol 120: 30-35.

21. Kim YR, Do JM, Kim KH, Stoica AR, Jo SW, et al. (2019) C-phycocyanin from Limnothrix species KNUA002 alleviates cisplatin-induced ototoxicity by blocking the mitochondrial apoptotic pathway in auditory cells. Mar Drugs 17(4): 235.

22. Borse V, Al Aameri RFH, Sheehan K, Sheth S, Kaur T, et al. (2017) Epigallocatechin-3-gallate, a prototypic chemopreventative agent for protection against cisplatin-based ototoxicity. Cell Death Dis 8(7): e2921.

23. Bhatta P, Dhukhwa A, Sheehan K, Al Aameri RFH, Borse V, et al. (2019) Capsaicin Protects Against Cisplatin Ototoxicity by Changing the STAT3/ STAT1 Ratio and Activating Cannabinoid (CB2) Receptors in the Cochlea. Sci Rep 9(1): 4131.

24. Freyer DR, Chen L, Krailo MD, Knight K, Villaluna D, et al. (2017) Effects of sodium thiosulfate versus observation on development of cisplatininduced hearing loss in children with cancer (ACCL0431): a multicentre, randomised, controlled, open-label, phase 3 trial. Lancet Oncol 18(1): 63-74.

25. Brock PR, Maibach R, Childs M, Rajput K, Roebuck D, et al. (2018) Sodium thiosulfate for protection from cisplatin-induced hearing loss. N Engl J Med 378(25): 2376-2385.

26. Dósa E, Heltai K, Radovits T, Molnár G, Kapocsi J, et al. (2017) Dose escalation study of intravenous and intra-arterial $\mathrm{N}$-acetylcysteine for the prevention of oto- and nephrotoxicity of cisplatin with a contrastinduced nephropathy model in patients with renal insufficiency. Fluids Barriers CNS 14(1): 26.

27. Li H, Song Y, He Z, Chen X, Wu X, et al. (2018) Meclofenamic acid reduces reactive oxygen species accumulation and apoptosis, inhibits excessive autophagy, and protects hair cell-like HEI-OC1 cells from cisplatininduced damage. Front Cell Neurosci 12: 139.

28. Kaur T, Borse V, Sheth S, Sheehan K, Ghosh S, et al. (2016) Adenosine A1 receptor protects against cisplatin ototoxicity by suppressing the NOX3/ STAT1 inflammatory pathway in the cochlea. J Neurosci 36(14): 39623977.

29. Ghosh S, Sheth S, Sheehan K, Mukherjea D, Dhukhwa A, et al. (2018) The endocannabinoid/cannabinoid receptor 2 system protects against cisplatin-induced hearing loss. Front Cell Neurosci 12: 271. 
30. Pang J, Xiong H, Zhan T, Cheng G, Jia H, et al. (2019) Sirtuin 1 and autophagy attenuate cisplatin-induced hair cell death in the mouse cochlea and zebrafish lateral line. Front Cell Neurosci 12: 515.

31. Hakiminia B, Goudarzi A, Moghaddas A (2019) Has vitamin E any shreds of evidence in cisplatin-induced toxicity. J Biochem Mol Toxicol 33(8): e22349.

32. Villani V, Zucchella C, Cristalli G, Galiè E, Bianco F, et al. (2016) Vitamin E neuroprotection against cisplatin ototoxicity: Preliminary results from a randomized, placebo-controlled trial. Head Neck 38(S1): E2118-E2121.

33. Simsek G, Taş BM, Muluk NB, Azman M, Kılıç R (2019) Comparison of the protective efficacy between intratympanic dexamethasone and resveratrol treatments against cisplatin-induced ototoxicity: an experimental study. Eur Arch Otorhinolaryngology 276(12): 3287-3293.

34. Ge Y, Zheng N, Chen X, Zhu J, Sun W, et al. (2019) GMDTC chelating agent attenuates cisplatin-induced systemic toxicity without affecting antitumor efficacy. Chem Res Toxicol 32(8): 1572-1582.

35. Fox E, Levin K, Zhu Y, Segers B, Balamuth N, et al. (2018) Pantoprazole, an Inhibitor of the Organic Cation Transporter 2, Does Not Ameliorate Cisplatin-Related Ototoxicity or Nephrotoxicity in Children and Adolescents with Newly Diagnosed Osteosarcoma Treated with Methotrexate, Doxorubicin, and Cisplatin. Oncologist 23(7): 762-769.

36. Sarafraz Z, Ahmadi A, Daneshi A (2018) Transtympanic injections of $\mathrm{N}$-acetylcysteine and dexamethasone for prevention of cisplatininduced ototoxicity: Double blind randomized clinical trial. Int Tinnitus J 22(1): 40-45.

37. Sheth S, Sheehan K, Dhukhwa A, Al Aameri RFH, Mamillapalli C, et al. (2019) Oral Administration of Caffeine Exacerbates Cisplatin-Induced Hearing Loss. Sci Rep 9(1): 9571.
38. Liu T, Zong S, Luo P, Qu Y, Wen Y, et al. (2019) Enhancing autophagy by down-regulating GSK-3 $\beta$ alleviates cisplatin-induced ototoxicity in vivo and in vitro. Toxicol Lett 313: 11-18.

39. Saha S, Panigrahi DP, Patil S, Bhutia SK (2018) Autophagy in health and disease: A comprehensive review. Biomed Pharmacother 104: 485-495.

40. Antunes F, Erustes AG, Costa AJ, Nascimento AC, Bincoletto C, et al. (2018) Autophagy and intermittent fasting: the connection for cancer therapy? Clinics (Sao Paulo) 73(S 1): e814s.

41. De Araujo JG, Serra LSM, Lauand L, Kückelhaus SAS, Sampaio ALL (2019) Protective effect of melatonin on cisplatin-induced ototoxicity in rats. Anticancer Res 39(5): 2453- 2458

42. Freyer DR, Brock PR, Chang KW, Dupuis LL, Epelman S, et al. (2020) Prevention of cisplatin-induced ototoxicity in children and adolescents with cancer: a clinical practice guideline. Lancet Child Adolesc Health 4(2): 141-150.

43. van As JW, van den Berg H, van Dalen EC (2019) Medical interventions for the prevention of platinum-induced hearing loss in children with cancer. Cochrane Database Syst Rev 16(5): CD009219.

44. Crabb SJ, Martin K, Abab J, Ratcliffe I, Thornton R, et al. (2017) COAST (Cisplatin ototoxicity attenuated by aspirin trial): A phase II doubleblind, randomised controlled trial to establish if aspirin reduces cisplatin induced hearing-loss. Eur J Cancer 87: 75-83. 